\title{
Seismic Analysis of Multi Storey Building with Flat Slab Resting on Plain and Sloping Ground
}

\author{
P. Manjunath and Yogeendra R. Holebsgilu
}

\begin{abstract}
The buildings are present in sloping ground are very different from those in plain ground, in sloping ground the buildings are very irregular and unsymmetrical in horizontal and vertical planes. The buildings in sloping ground causes more damage during earthquake, because in sloping ground the structure is constructed with different column heights. In this study 3D analytical model of 10 storied building, the plan of each configuration includes 4 bays in $Y$ direction and 6 bays in $X$ direction which is kept same for all configurations of building frame, the slope chosen in between 0 to 30 degree. The building is located on seismic zone $V$, with different soil type; the models are analyzed and designed by ETABS 2015 software. Seismic analysis done by linear dynamic analysis (RSA). I concluded that the effect soil is more important on the earthquake performance of structure. As the soil stiffness increase the building performance increase by earthquake loads, the study also possess that in response spectrum analysis the performance of the building in sloping ground is more danger to earthquake than that of building present in plain ground.
\end{abstract}

Keywords--- Flat Slab, Plain and Sloping Ground, Response Spectrum, ETABS 2015.

\section{INTRODUCTION}

$\mathrm{T}$ HE term earthquake can be used to describe any kind of seismic waves which may be either natural or introduced by humans, which generates seismic waves. Earthquakes are caused commonly by break of geological faults. An energy release in the earth's crust which generates seismic wave's results an earthquake. The frequency, type and magnitude of earthquakes experienced over a period of time define the seismicity (seismic activity) of that area. At present time the methods of seismic evaluation for the seismic damage or earthquake damaged structures are not yet fully developed. The buildings which do not fulfill the requirements of seismic design, may suffer extensive damage or collapse if shaken by a severe ground motion or earthquake.

Earthquake is the major reason for the issue of safety for the construction of multi storey buildings. The buildings which are present now are designed and constructed according to as per older code provisions, are not satisfying. Therefore it is need to construct different types of buildings which have the capacity to resist the forces, like Flat Slab and RC Framed

P. Manjunatha, PG Student, Department of Civil Engineering, Government Engineering College, Haveri, Karnataka, India. E-mail:manju.pattar15@gmail.com

Yogeendra R. Holebagilu, Assistant Professor, Department of Civil Engineering, Government Engineering College, Haveri, Karnataka, India. DOI:10.9756/BIJMMI.8150 structure buildings are more suitable for now a day, because of increased in population and the land value.

Buildings are present in hilly areas are very different from those in plain ground; in hilly areas they are very irregular and unsymmetrical. Hence, they tend to severe damage to the structure when affected by earthquake, because in hilly areas the structure is constructed with different column heights, the short column will affects more damage than the long column during earth quake. The constructions of multi-storey flat slab building in level ground is better than in the construction on the sloping in ground, during earthquake the construction of building in sloping ground causes more damage to the structure and it is unsafe for the structure, the materials like burnt brick, stone masonry \& dressed stone masonry buildings are generally made over level ground in sloping ground. Since level land in hilly regions is very limited, there is a more demand to construct buildings on sloping ground. In some parts of world, sloping ground is more danger to earthquake ground motion; e.g. northeast region of India.

The construction of framed structure is to support the slabs by beams and support the beams by columns. This may be called as RC Framed structure or Beam-Slab construction. The beams reduce the available clear maximum height, hence in warehouses, offices and public halls sometimes beams are avoided and slabs are directly supported by columns. A flat slab is a reinforced in one or more direction usually without beams and loads are directly transfer to the support members, these types of construction are called flat slabs.

\section{A. Objectives of Work}

The main aim of this work is to study the static, dynamic analysis and performance of flat slab building on plain ground and sloping ground at various slopes under seismic excitation. The objective of study is as follows:

Three dimensional space frame analysis is carried out for flat slab building of 10 storey resting on plain ground and sloping ground with slope angles $10^{\circ}, 20^{\circ} \& 30^{\circ}$ to horizontal. Analysis is performed under the action of seismic load by using Etabs software. Response spectrum method of analysis is used, the results in terms of base shear, storey drift, frequency, storey acceleration, time period and displacement is obtained, and compared with the configuration in plain ground to the configurations in sloping ground. At the end, a suitable configuration of building to be used in hilly area is suggested. 
1. Response spectrum analysis is carried out for critical zones (i.e., V zone) as per IS 1893 (Part 1):2002 for different soil types i.e. 1, 2, and 3 (hard, medium and soft soil).

2. To compare the performance of RC frame of Plain Ground \& Sloping Ground with Flat Slab Structure, the column size is $550 \mathrm{mmX} 550 \mathrm{~mm} \&$ Drop size is $1600 \mathrm{mmX} 1600 \mathrm{~mm}$. In sloping ground the angles are taking from 0 to 30 degrees along the horizontal length of the building.

3. Etab software is used for the RC frame model to know the results in form of time period, frequency, base shear, acceleration, displacement and storey drift results are compared for purely frame, purely flat plate and seismic strengthened flat plate models and the analysis is done with Etabs 2015 software.

\section{METHOD OF ANALYSIS OF STRUCTURE}

As per the Indian Standard code for Earthquake IS: 18932002, seismic analysis can be performed by three methods.

1. Static Method
A. Equivalent Static Linear Method

2. Dynamic Methods
A. Response Spectrum Method
B. Time History Method

In present work Response Spectrum Method is used for analysis

\section{A. Response Spectrum Method}

The seismic analysis for all buildings in plain and sloping ground, the slope angles are 0 to 30 degree are carried out by response spectrum method by using IS: 1893(part-I) -2002 . The other parameters used in seismic analysis are, moderate seismic zone (V), zone factor 0.36 , importance factor $1.5,5 \%$ damping and response reduction factor 5.0, the building frame system is special RC moment-resisting frame (SRMF) frame for all configurations and height of buildings.

As per codal provision, dynamic results were normalized by multiplying with a base shear ratio, $\lambda=\mathrm{Vb} / \mathrm{VB}$, where $\mathrm{Vb}$ is the base shear evaluation based on time period given by empirical equation and, VB is the base shear from dynamic analysis , if $\mathrm{Vb} / \mathrm{VB}$ ratio is more than one.

\section{DETAILS OF THE MODELS}

In the present study, one building configurations are considered, which include buildings situated on plain ground and sloping ground (0 to 30 degree). Number of storey considered for each type of configurations is 10 storey's. Plan layout of each configuration includes 4 bays across the $\mathrm{Y}$ direction and 6 bays are considered along $\mathrm{X}$ direction, which is kept same for all configurations of building frame with flat slab. The supports are taken to be square to avoid the matters like alignment. The depth of footing below ground level is taken as $1.5 \mathrm{~m}$ where, the hard soil is available.
Table 1: General Data of the Building

\begin{tabular}{|c|c|c|}
\hline Sl. No. & Description & Data \\
\hline 1 & Number of Stories & 10 \\
\hline 2 & The building Frame system & SMRF \\
\hline 3 & Building Use & Commercial \\
\hline 4 & Floor Height & 3.5 meter \\
\hline \multirow{3}{*}{5} & \multirow{3}{*}{ Types of soil } & Hard \\
\hline & & Medium \\
\hline & & Soft \\
\hline 6 & Support Condition & Fixed \\
\hline \multicolumn{3}{|c|}{ Material Properties } \\
\hline 7 & Grade of Concrete & M30 \\
\hline 8 & Grade of Steel & $\mathrm{Fe} 500$ \\
\hline 9 & Young's modules of Concrete & $5000 \sqrt{\text { fck }}$ \\
\hline 10 & Density of Concrete & $25 \mathrm{kN} / \mathrm{m}^{3}$ \\
\hline 11 & Poisson's ratio & 0.2 \\
\hline \multicolumn{3}{|c|}{ Structural Members } \\
\hline 12 & Column Size & $550 \mathrm{~mm} \times 550 \mathrm{~mm}$ \\
\hline 13 & Drop Size & $1600 \mathrm{~mm} \times 1600 \mathrm{~mm}$ \\
\hline 14 & Thickness of Drop & $300 \mathrm{~mm}$ \\
\hline 15 & Thickness of Slab & $200 \mathrm{~mm}$ \\
\hline \multicolumn{3}{|c|}{ Assumed dead load intensity } \\
\hline 16 & Live load on floors & $4 \mathrm{kN} / \mathrm{m}^{2}$ \\
\hline 17 & Floor finish & $1.5 \mathrm{kN} / \mathrm{m}^{2}$ \\
\hline \multicolumn{3}{|c|}{ Earthquake parameters } \\
\hline 18 & Importance factors, I & 1.5 \\
\hline 19 & Time period, $\mathrm{t}$ & $0.075 h^{0.75}$ \\
\hline 20 & Zone, V & 0.36 \\
\hline 21 & Response reduction factor & 5 \\
\hline
\end{tabular}

\section{A. Building Models}

The models which are considered for the present work are developed using ETABS-2015 structural software. In the present study four set of buildings are considered the plan of the model is same for all set, but only an angle will changes ( 0 to $30 \mathrm{deg}$ ). Set-1 is resting on a plain ground where as set-2 is resting on a sloping ground at an angle of $10^{\circ}$ and set- 3 is resting on a sloping ground at an angle of $20^{\circ}$. The Set- 4 is resting on a sloping ground at an angle of $30^{\circ}$ are respectively the buildings on a plain \& varying sloping ground with flat slabs, Set-1 is the building model on plain ground, the slope of the ground is $10,20 \& 30$ degree with horizontal for set-2, set$3 \&$ set- 4 . The models are shown in below figures.

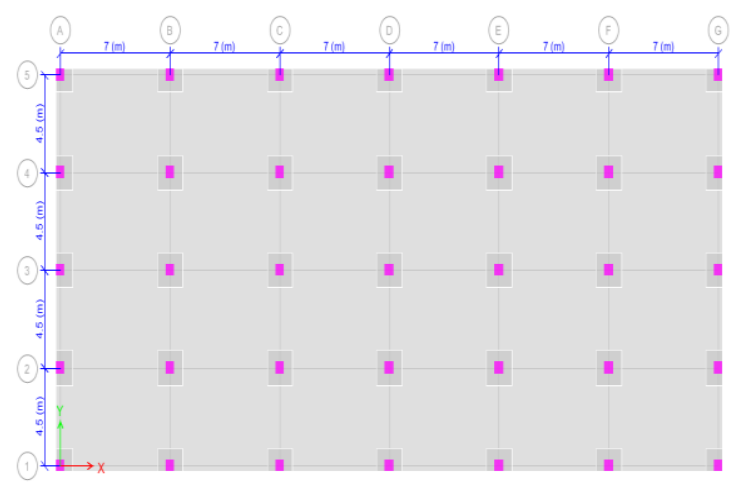

Figure 1: Plan of the Model with Flat Slab 


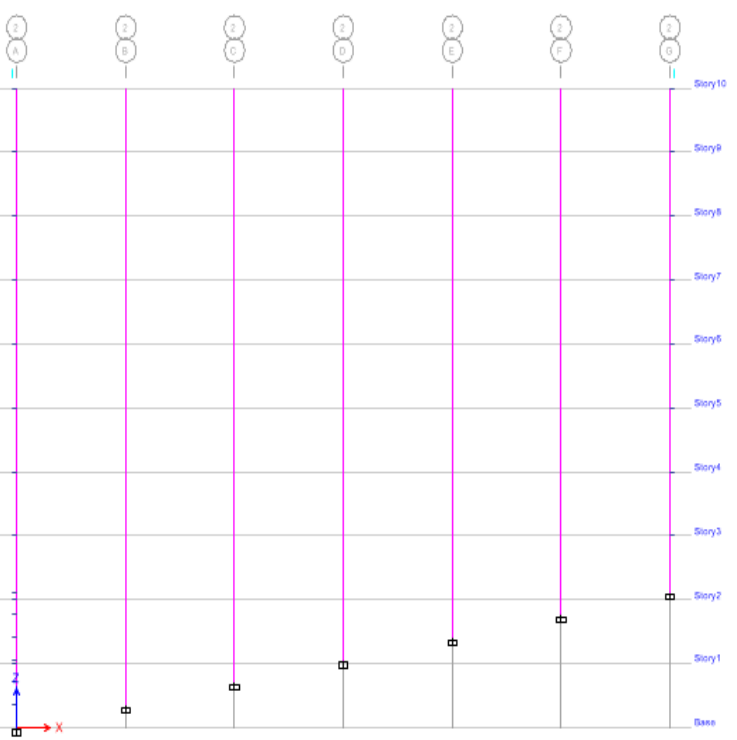

Figure 2: Elevation of the Model at 100 Slope

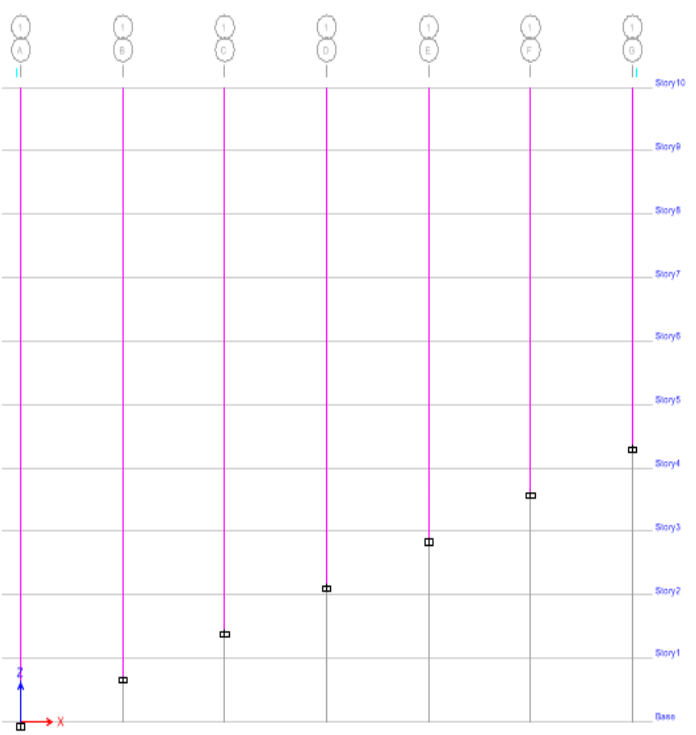

Figure 3: Elevation of the Model at 200 Slope

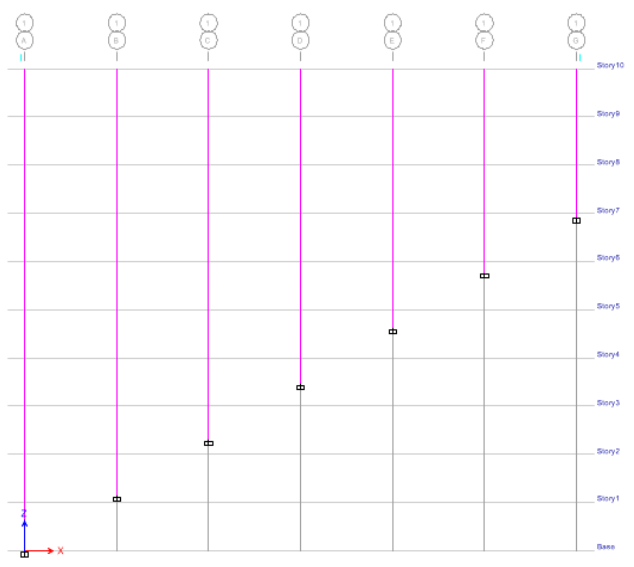

Figure 4: Elevation of the Model at 300 Slope

\section{RESULTS AND DISCUSSION}

In this study the building with flat slab resting on plain ground and sloping ground, the sloping angles are 10 degree to 30 degree the angle varying along horizontal length of the building. However to know the further detail's study of the building on the sloping ground it would be interesting to know the response to earthquake force for real building's. Hence four set's are considered, the plan of the building is same for all 4 set's i.e.set. 1 on a plain ground, set. 2 on a sloping ground at an angle $10^{\circ}$, set. 3 on a sloping ground at an angle $20^{\circ}$ and set. 3 on a sloping ground at an angle $30^{\circ}$ have been considered for the study.

The results are discussed based on the four model's and are presented in detail. It includes ten storey building model and the corresponding results are computed by response spectrum analysis. These results are analyzed and performed by ETABS 2015 software.

The results are seismic base shear, lateral displacement, storey acceleration, frequency/time period and storey drift are compared for all the 4 set's of the building.

Table 2: Base Shear (in $\mathrm{kN}$ )

\begin{tabular}{|c|c|c|c|c|c|}
\hline \multirow[t]{2}{*}{ Zone } & \multirow[t]{2}{*}{ Soil Type } & $0^{\circ}$ & $10^{\circ}$ & $20^{\circ}$ & $30^{\circ}$ \\
\hline & & \multicolumn{4}{|c|}{ BASE SHEAR IN $(k N)$} \\
\hline \multirow[t]{3}{*}{$\mathrm{V}$} & 1 & 4003.62 & 3688.47 & 3231.37 & 2639.83 \\
\hline & 2 & 5444.93 & 5016.32 & 4394.67 & 3590.17 \\
\hline & 3 & 6686.05 & 6159.74 & 5396.39 & 4408.51 \\
\hline
\end{tabular}

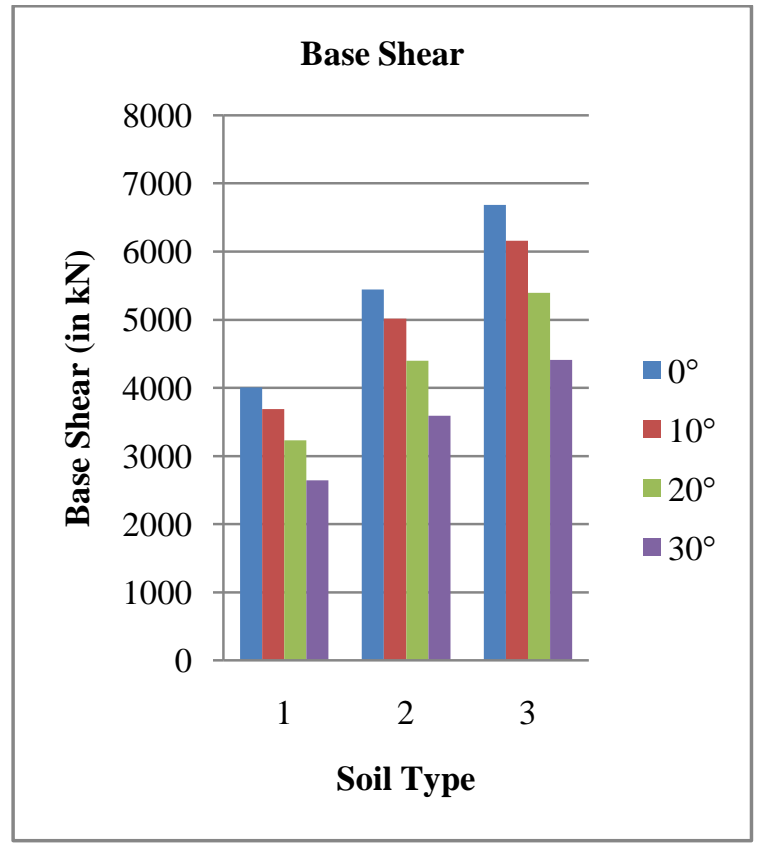

Figure 5: Base Shear in Different Soil 


\section{Discussion}

\section{Base Shear}

- The Base Shear in the $0^{\circ}$ (plain ground) base slope building is more due to this increase in seismic weight of the structure.

- The base shear will decrease as the slope of the angle increases due to this decrease in seismic weight of the structure.

- From the results it can be seen that as the soil becomes loose the base shear will also increase due to the reduction in stiffness and modules of elasticity of soil.

- From the results it can be observed that the building is resting on plain ground is safe during earthquake ground motions, than the building resting on sloping ground. Hence the building on sloping ground has more danger to the earthquake ground motions.

Table 3: Maximum Displacement

\begin{tabular}{|l|l|l|l|l|l|}
\hline \multirow{2}{*}{ Zone } & \multirow{2}{*}{ Soil Type } & \multicolumn{4}{|l}{ MAXIMUM DISPLACEMENT (in mm) } \\
\cline { 3 - 6 } & & $0^{\circ}$ & $10^{\circ}$ & $20^{\circ}$ & $30^{\circ}$ \\
\hline \multirow{3}{*}{$\mathrm{V}$} & 1 & 127.4 & 98.9 & 16.6 & 0.1 \\
\cline { 2 - 6 } & 2 & 177.6 & 135.6 & 23.4 & 0.3 \\
\cline { 2 - 6 } & 3 & 218.1 & 168.5 & 29.5 & 0.4 \\
\hline
\end{tabular}

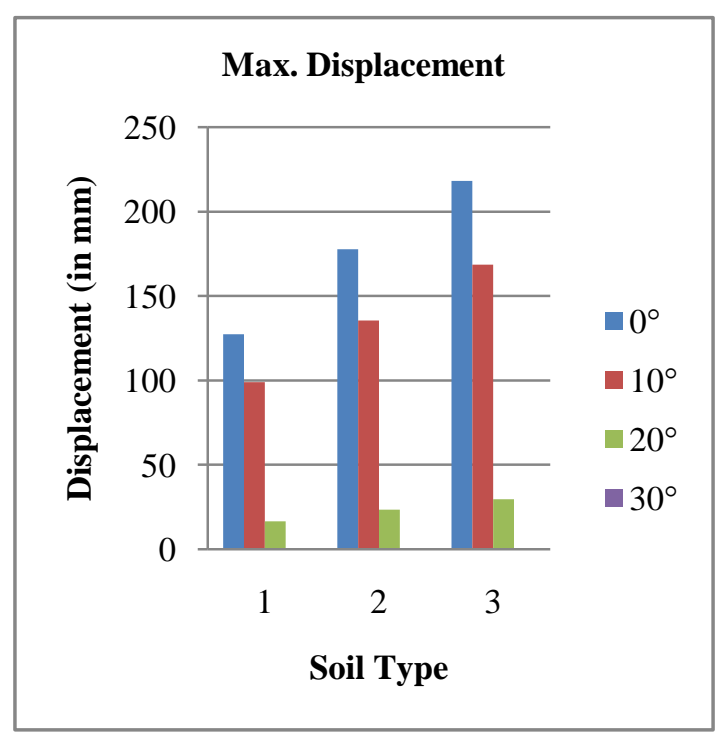

Figure 6: Max. Displacement in Different Soil

Table 4: Peak Accelerations

\begin{tabular}{|l|l|l|l|l|l|}
\hline Zone & Soil Type & \multicolumn{4}{|l|}{ Accelerations in $\left(\mathrm{mm} / \mathrm{sec}^{2}\right)$} \\
\cline { 3 - 6 } & & $0^{\circ}$ & $10^{\circ}$ & $20^{\circ}$ & $30^{\circ}$ \\
\hline $\mathrm{V}$ & 1 & 1859.28 & 1678.88 & 634.76 & 11.86 \\
\cline { 2 - 6 } & 2 & 2277.67 & 2051.62 & 750.43 & 21.01 \\
\cline { 2 - 6 } & 3 & 2603.56 & 2519.27 & 843.21 & 30.02 \\
\hline
\end{tabular}

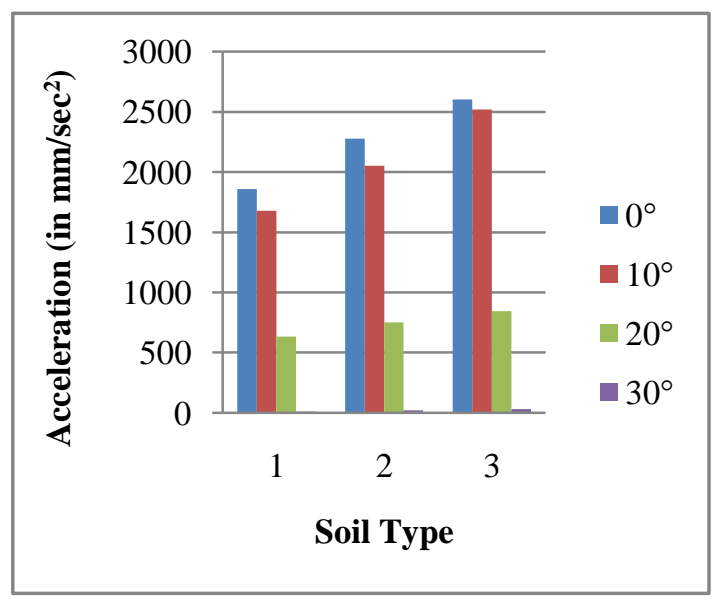

Figure 7: Acceleration in Different Soil

\section{Displacement and Accelerations}

- Displacement and Acceleration of the structure decrease with increase in the slope of ground at the base of the structure.

- It is because as the slope increase the fixity for the structure at different heights increase and as the fixity is increased, the stiffness of the structure increases which results in decrease in maximum displacement and acceleration of structure.

- And also as the stiffness in the soil is also reduces the displacement of the structure will also increase.

Table 5: Maximum Drift

\begin{tabular}{|l|l|l|l|l|l|}
\hline \multirow{2}{*}{ Zone } & \multirow{2}{*}{ Soil Type } & \multicolumn{4}{|l|}{ MAXIMUM DRIFT IN $(\mathrm{mm})$} \\
\cline { 3 - 6 } & & $0^{\circ}$ & $10^{\circ}$ & $20^{\circ}$ & $30^{\circ}$ \\
\hline \multirow{3}{*}{$\mathrm{V}$} & 1 & 5.386 & 4.959 & 1 & 0.015 \\
\cline { 2 - 6 } & 2 & 7.506 & 6.791 & 1.403 & 0.028 \\
\cline { 2 - 6 } & 3 & 9.217 & 8.425 & 1.768 & 0.041 \\
\hline
\end{tabular}

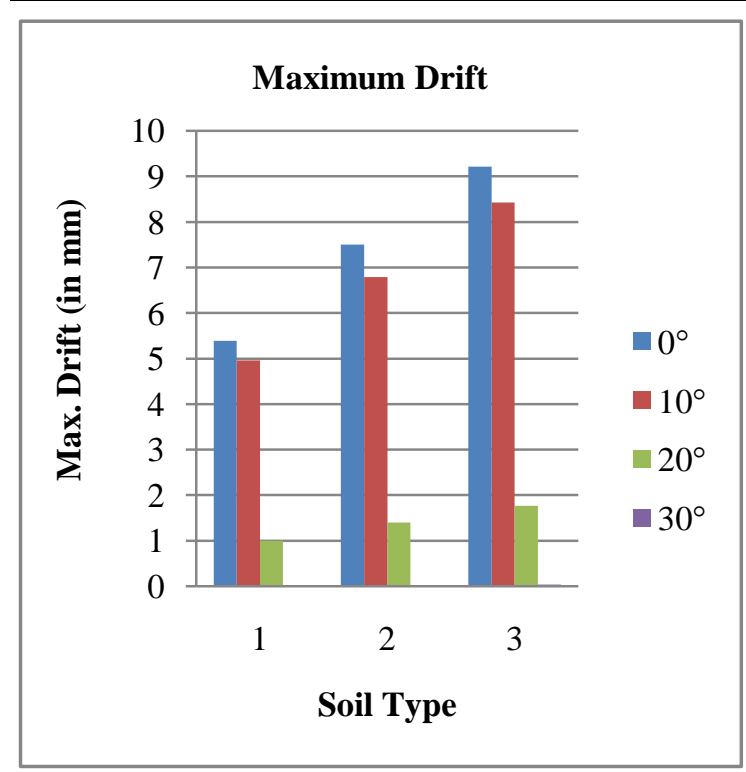

Figure 8: Max. Drift in Different Soil 


\section{Storey Drift}

- Drift in the structure where base slope is more have very less drift.

- It is also mainly becomes of the mass participation is less and hence drift reduces.

- Maximum storey drift is more at the bottom story but these storey are subjected to more fixity and hence drift is almost nill at these stories.

- As seen in results the maximum storey drift also very depends on the type of soil.

- As the stiffness of soil reduces the drift will increase.

Table 6: Frequency/Time for 1 st Mode

\begin{tabular}{|c|c|c|c|c|c|c|}
\hline Soil Type & 1 & 2 & 3 & 1 & 2 & 3 \\
\hline Degree & \multicolumn{3}{|c|}{ Frequency $(\mathrm{Hz})$} & \multicolumn{3}{|c|}{ Time $(\mathrm{Sec})$} \\
\hline $0^{\circ}$ & 0.375 & 0.375 & 0.375 & 2.67 & 2.67 & 2.67 \\
\hline $10^{\circ}$ & 0.465 & 0.465 & 0.465 & 2.151 & 2.151 & 2.151 \\
\hline $20^{\circ}$ & 0.62 & 0.62 & 0.62 & 1.613 & 1.613 & 1.613 \\
\hline $30^{\circ}$ & 1.369 & 1.369 & 1.369 & 0.731 & 0.731 & 0.731 \\
\hline
\end{tabular}

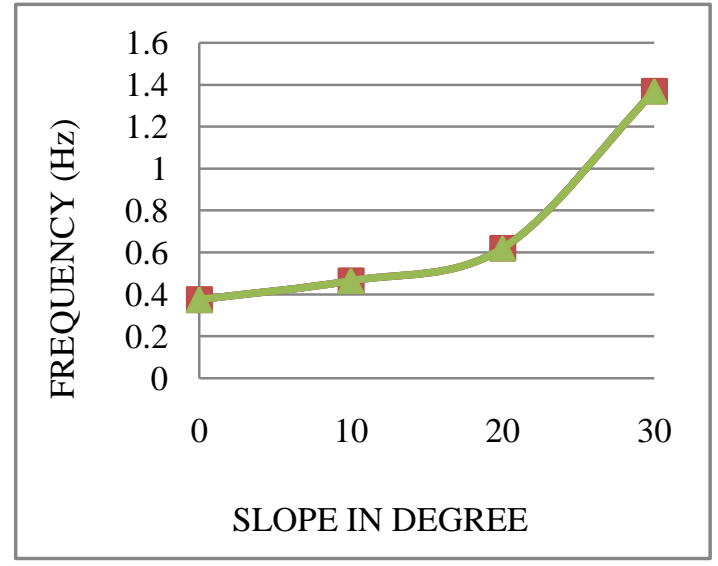

Figure 9: Frequency for 1st Mode

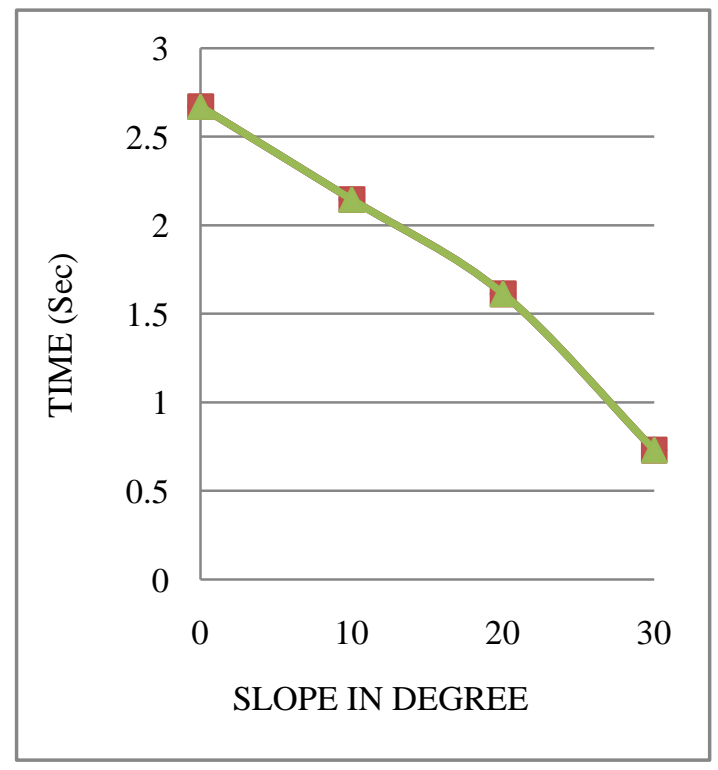

Figure 10: Time for 1st Mode

\section{Frequency and Time period}

- The frequency of the structure increase with increases in slope of the ground at the base. This is mainly becomes of decrease in height of structure at the height base point. Hence also time reduces.

- The time period will decrease as the slope of the angle increases at the base of the ground.

- Natural time period and Natural frequency much depends on the type of soil mainly becomes there is no additional changes in the structure.

\section{CONCLUSION}

The results are obtained with the help of dynamic linear analysis the effect of base shear, displacement, storey drift, time period; frequency and storey force are compared. These are conclusion obtained from this analysis:

1. As the slope of the base increases it results in decrease in seismic weight.

2. Base shear will be very less in sloping ground compared to that on level ground.

3. Displacement and Acceleration of the structure gets reduced as the effective height of the structure will reduce resulting in increase in fixity of structure.

4. Storey drift is more in on the plain ground compared to that on the sloping ground this is due to increase in fixity and reduces in number of stories.

5. Effect of soil is more important on the earthquake performance of structure. As the soil stiffness increase the building performance increase by earthquake loads.

6. For stiffer soil the displacement, acceleration and drift decreases. Compared to that of loose soil.

7. The study also posses that in static linear method and response spectrum analysis the performance of the building on sloping ground has more danger to earthquake than that of building present in plain ground.

\section{REFERENCES}

[1]. B. Shivanand and H.S. Vidyadhara, "Design Of 3d Rc Frame On Sloping Ground", Ijret, Vol. 3, No. 8, 2014.

[2]. Y. Singh, P. Gade, D.H. Lang and E. Erduran, "Seismic Behaviour of Buildings Located on Slopes-An Analytical Study and Some Observations from Sikkim Earthquake of 18th September 2011. In The 15 th World Conference on Earthquake Engineering, Lisbon, Portugal, 2012.

[3]. K. Sujit, V. Garg and A. Sharma, "Effect of Sloping Ground On Structural Performance Of Rcc Building Under Seismic Load", Ijset, Vol. 2, No. 6, 2014.

[4]. K.S.L. Nikhila and Dr.B. Pandurangarao, "Static Linear and Nonlinear Analysis of R.C Building on Sloping Ground with Varying Hill Slopes" AJER, Vol. 3, No. 11, Pp-70-76.

[5]. K. Navyashree and T.S. Sahana, "Use of Flat Slabs in Multi-Storey Commercial Building Situated In High Seismic Zone", Ijret, Vol. 3, No. 8,2014

[6]. K. Ramin and F. Mehrabpour, "Study of short column behavior originated from the level difference on sloping lots during earthquake", Open Journal of Civil Engineering, 2014.

[7]. R.S. More, V.S. Sawant, and Y.R. Suryawanshi, "Analytical Study of Different Types of Flat Slab Subjected to Dynamic Loading", IJSR, Vol. 4, No. 7, 2015.

[8]. H.S. Basavaraj and B.A. Rashmi, "Seismic Performance of R C FlatSlabBuilding Structural Systems”, Vol. 2, No. 9, 2015. 
[9]. P.N. Sanjay, K. Mahesh Prabhu, and S.S. Umesh, "Behaviour of Flat Slab Rcc Structure UnderEarthquake Loading”, IJERT, Vol. 3, No. 5, 2014.

[10]. S.A. Halkude, M.G. Kalyanshetti and V.A. Kadlag, "Pushover Analysis of R.C Frames Considering Soil Structure Interaction", IJCET, Vol. 5, No. 1, 2015.

[11]. Indian Standard, IS 456-2000 "Plain and Reinforced Concrete-Code of Practice", Bis, New Delhi, India.

[12]. Indian Standard Is 1893-2002, "Creteriafor Earthquake Resistant Design of Structures", Part 1: General Provisions and Buildings, Fifth Revision, Bis, New Delhi, India. 